\title{
Egr-1 is not upregulated in response to hypoxic and oxygenation conditions in human glioblastoma in vitro
}

\author{
HARUN M. SAID ${ }^{1}$, BUELENT POLAT ${ }^{1}$, CARSTEN HAGEMANN ${ }^{2}$, GILES H. VINCE ${ }^{2}$, JELENA ANACKER ${ }^{3}$, \\ ULRIKE KÄMMERER ${ }^{3}$, MICHAEL FLENTJE $^{1}$ and DIRK VORDERMARK ${ }^{1,4}$
}

\author{
Departments of ${ }^{1}$ Radiation Oncology, ${ }^{2}$ Neurosurgery, ${ }^{3}$ Gynecology and Obstetrics, University of Würzburg, Würzburg; \\ ${ }^{4}$ Department of Radiation Oncology, Martin Luther University of Halle-Wittenberg, Germany
}

Received 23 October 2008; Accepted 2 March, 2009

DOI: $10.3892 / \mathrm{mmr} 00000169$

\begin{abstract}
The early growth response factor 1 (Egr-1) gene (also known as krox24, NGFI-A, TIS8 or zif268) belongs to a family of immediate early response genes. This family of proteins contains a conserved zinc finger DNA-binding domain and can bind to a GC-rich sequence in the promoter region of target genes. Egr-1 expression is rapidly and transiently activated in many different cell types during development. In adult tissues, a variety of signals, including serum, growth factors, cytokines and hormones, stimulate Egr-1 expression. In several studies, it was demonstrated that the transcription factor Egr-1 is regulated by hypoxia, and it is hypothesized that Egr-1 is responsible for the hypoxia-induced regulation of the N-Myc downregulated gene 1 (NDRG1) in human tumor cells. In the present study, Egr-1 regulation was examined in the human glioblastoma cell lines U373, U251, GaMG and U87-MG under extreme hypoxic aeration conditions $\left(0.1 \% \mathrm{O}_{2}\right)$ for 1,6 and $24 \mathrm{~h}, 24$-h extreme hypoxia with reoxygenation for 24 and $48 \mathrm{~h}$, respectively, as well as oxygenated conditions $\left(21 \% \mathrm{O}_{2}\right.$ and $5 \% \mathrm{CO}_{2}$ ) in vitro. Protein and mRNA levels were detected in the lysates by Western blotting and RT-PCR, respectively. Egr-1 expression under hypoxic conditions was compared with the well-known and characterized hypoxia-induced gene regulator hypoxia-inducible factor- $1 \alpha(\mathrm{HIF}-1 \alpha)$ in parallel experimental sets. Cells incubated for $24 \mathrm{~h}$ with $100 \mu \mathrm{M}$ desferroxamine served as a positive control for hypoxia, and $\beta$-tubulin and $\beta$-actin were used as loading controls. The experimental data indicate that Egr-1 was not upregulated under extreme hypoxic conditions $\left(0.1 \% \mathrm{O}_{2}\right)$ or by reoxygenation after hypoxia in different glioblastoma cells in vitro. In conclusion, the regulation of Egr-1 in reaction to hypoxic
\end{abstract}

Correspondence to: Dr Harun M. Said, Department of Radiation Oncology, University of Würzburg, Josef-Schneider-Str. 11, 97080 Würzburg, Germany

E-mail: said_h@klinik.uni-wuerzburg.de

Key words: hypoxia-inducible factor $1 \alpha$, early growth response factor 1, hypoxia, glioblastoma, reoxygenation, N-Myc downregulated gene 1 development, at both the protein and mRNA levels, is not a general phenomenon. In contrast to previously published data, no Egr-1 regulatory events were observed in glioblastoma under hypoxic conditions in vitro. We suggest that Egr-1 regulation in human tumors in reaction to hypoxia could be a cell-specific post-translational event. Therefore, at least in glioblastoma, HIF-1 $\alpha$ can be considered a major regulator of NDRG1 under hypoxic conditions. Further extensive analysis of tumor cells from different origins under similar physiological conditions is necessary to increase our knowledge of the conditions and functional role of Egr-1 in the regulation of hypoxia-induced gene expression.

\section{Introduction}

Early growth response factor 1 (Egr-1) is a transcription factor that triggers the transcription of downstream genes within 15-30 min of various stimulations (1). It has been reported in several publications $(2,3)$ that Egr-1 is regulated by hypoxia, and it is hypothesized that Egr-1 is responsible for the hypoxia-induced regulation of $\mathrm{N}$-myc downregulated gene 1 (NDRG1) in human tumor cells. Hypoxia-inducible factor 1 (HIF-1) is a transcription factor consisting of two subunits, HIF- $1 \alpha$ and HIF-1 $\beta$, which are basic-helix-loop-helix proteins containing a PAS domain (4). In normoxia, the von HippelLindau tumor suppressor, which is the recognition component of an E3 ubiquitin ligase complex, targets HIF-1 $\alpha(5,6)$, leading to its ubiquitylation and consequent proteasomal degradation (6-10). HIF-1 $\alpha$ is responsible for the regulation of several hypoxia-induced genes. These genes are expressed rapidly by HIF-1-specific promoter activation. HIF-1 binds to the hypoxia responsive element (HRE) and thereby mediates cell growth and angiogenesis $(11,12)$. Due to HRE positioning in the distal promoter region, HIF-1 also acts as a transcriptional enhancer, as hypothesized in a similar gene expression model (4). During hypoxia, the HIF- $1 \alpha / \beta$ heterodimer binds to the core pentanucleotide sequence (RCGTG) in the HREs of target genes. HIF-1 $\beta$ subunits are non-oxygen responsive nuclear proteins that also play various roles in transcription (13). In contrast, HIF-1 $\alpha$ subunits are highly inducible by different oxygenation conditions in human glioblastoma cells. There is a clear enhanced binding of HIF-1 $\alpha$ from nuclear extracts of glioblastoma cell samples exposed to extreme hypoxic conditions. Upregulation of HIF- $1 \alpha$ under these con- 

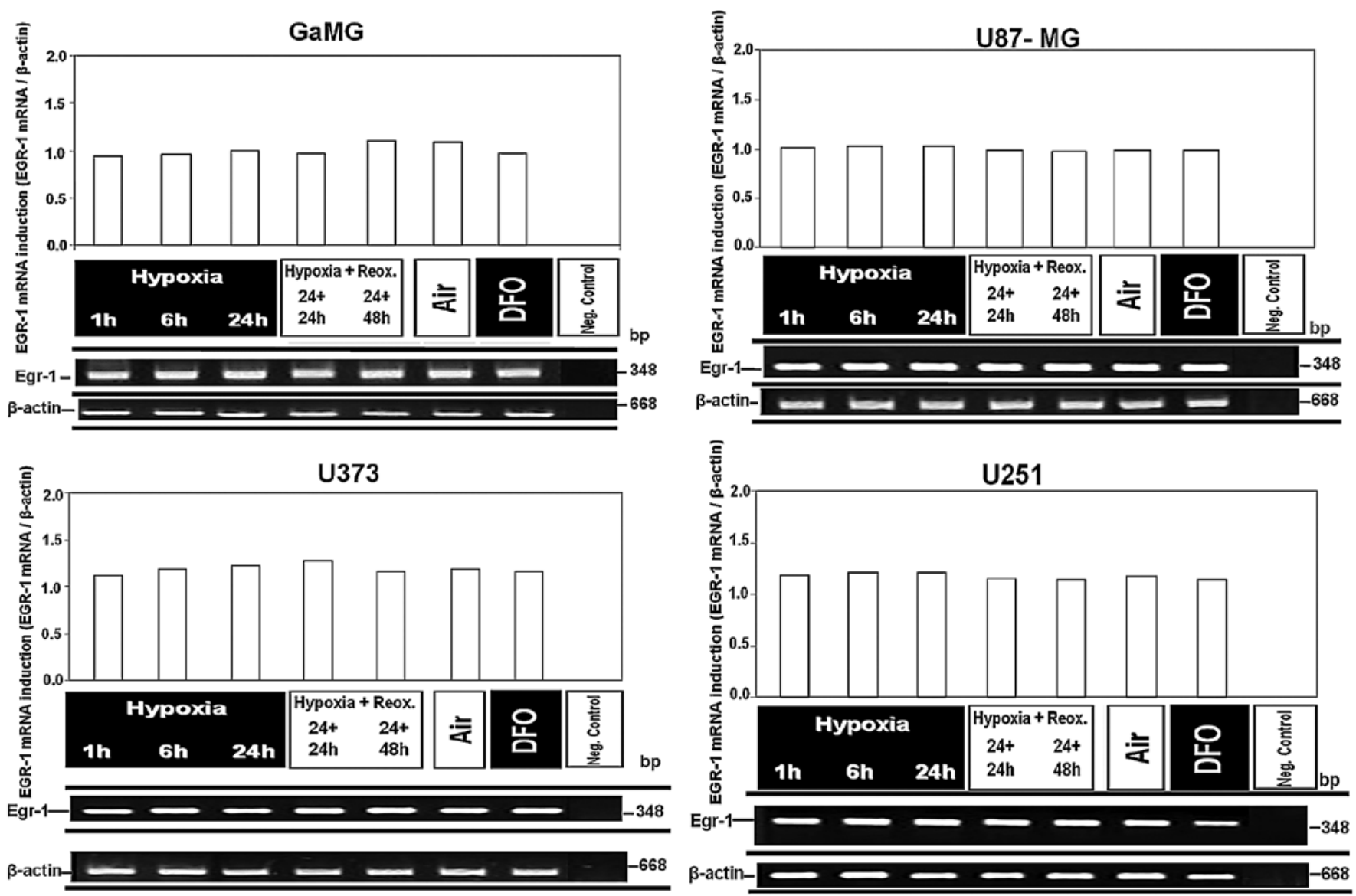

Figure 1. Early growth response factor 1 (Egr-1) mRNA expression under hypoxic conditions in glioblastoma in vitro. Examination of hypoxia-inducible regulation of Egr-1 gene expression at the mRNA level (semi-quantitative RT-PCR) in vitro in human glioblastoma cell lines (hypoxia time course experiments at an $\mathrm{O}_{2}$ concentration of $\left.0.1 \%\right)$. Glioblastoma cell lines were exposed to hypoxic conditions $\left(0.1 \% \mathrm{O}_{2}\right)$ for 1,6 or $24 \mathrm{~h}$. Total mRNA from cells subjected to $24 \mathrm{~h}$ under normoxia or to treatment with desferroxamine (DFO, $100 \mu \mathrm{M}$ ) served as the negative and positive control, respectively. RT-PCR did not reveal any regulatory events under different oxygenation, hypoxia and reoxygenation conditions. Bar graphs show band intensities after densitometric evaluation and normalization to $\beta$-actin expression. A representative experiment of three is shown.

ditions was confirmed by Western blotting $(14,15)$. Regulation of NDRG1 by HIF-1 $\alpha$ has also been demonstrated $(16,17)$.

Our findings indicate that EGR-1 is not upregulated in response to extreme hypoxic conditions $\left(0.1 \% \mathrm{O}_{2}\right)$ or reoxygenation after hypoxia in human glioblastoma. Therefore, HIF- $1 \alpha$ remains one of the most promising targets for new therapeutic strategies in cancer treatment, particularly in the therapeutic modulation of the adaptive hypoxic response. Based on our own data and the research of others, we believe that Egr-1 is not suitable as a new target for the therapeutic modulation of the adaptive hypoxic response, at least not in human glioblastoma.

\section{Materials and methods}

Cell culture and hypoxia treatment. The early-passage human malignant glioma cell lines U87-MG, U251 and U373 from the American Type Culture Collection (ATCC, Rockville, MD) and GaMG, a cell line established from a patient with glioblastoma multiforme (Gade Institut of the University Bergen, Norway) (18), were grown on glass Petri dishes in Dulbecco's modified Eagle's medium supplemented with $10 \%$ fetal bovine serum and non-essential amino acids.
Additionally, all culture media were supplemented with penicillin $(100 \mathrm{IU} / \mathrm{ml}) /$ streptomycin $(100 \mu \mathrm{g} / \mathrm{ml})$ and $2 \mathrm{mM}$ L-glutamine. In vitro hypoxia treatment of cultures was in a Ruskinn (Cincinnatti, OH, USA) Invivo ${ }_{2}$ hypoxic workstation as previously described (19) for 1,6 or $24 \mathrm{~h}$ at $0.1 \% \mathrm{O}_{2}$. Dishes were returned to the incubator after a 24-h hypoxia treatment for reoxygenation experiments.

Preparation of protein lysates from human tumor cells and immunoblotting. Tumor cell lysates were prepared with $0.1 \mathrm{ml}$ lysis buffer [1X Tris-buffered saline (TBS), $1 \%$ Nonidet P-40 (Amresco, Vienna, Austria), 0.5\% sodium deoxycholate, $0.1 \%$ SDS and the protease inhibitors pepstatin A $(1.4 \mu \mathrm{M})$, aprotinin $(0.15 \mu \mathrm{M})$, leupeptin $(2.3 \mu \mathrm{M}), \operatorname{PMSF}(100 \mu \mathrm{M})$ and phosphatase inhibitor mix (Sigma, St. Louis, MO, USA)]. Whole-cell lysates $(20 \mu \mathrm{g})$ were separated by SDS polyacrylamide gel electrophoresis (8\% gels) and transferred to a $0.45-\mu \mathrm{m}$ nitrocellulose membrane (Protran BA 85; Schleicher \& Schuell, Dassel, Germany). Non-specific binding was blocked by $5 \%$ nonfat milk powder in TBS overnight at $4{ }^{\circ} \mathrm{C}$ followed by incubation with the Egr-1 primary antibody sc-110 (Santa Cruz Biotechnology Inc., Santa Cruz, CA) diluted $1: 100$ in $1.0 \%$ nonfat milk powder in TBS for $1 \mathrm{~h}$ at room 

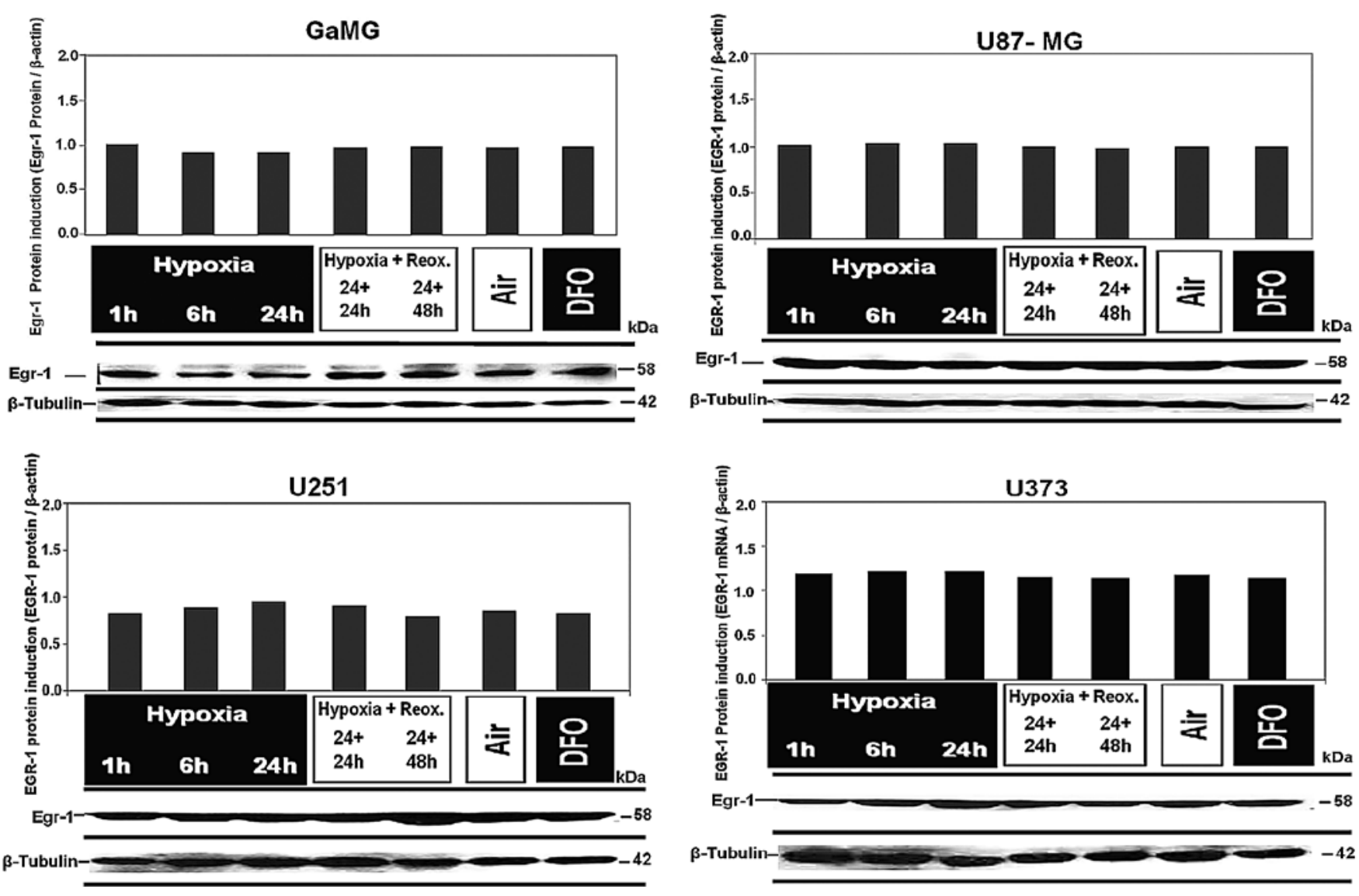

Figure 2. Early growth response factor 1 (Egr-1) protein expression under hypoxic conditions in glioblastoma in vitro. Regulation of Egr-1 expression at the protein level in vitro in human glioblastoma cell lines exposed to hypoxic conditions $\left(0.1 \% \mathrm{O}_{2}\right)$ for 1,6 or $24 \mathrm{~h}$. Protein lysates subjected to $24 \mathrm{~h}$ under normoxia or to treatment with desferroxamine (DFO, $100 \mu \mathrm{M}$ ) served as the negative and positive control, respectively. A representative experiment of three is shown.

temperature. Blots were washed twice in TBS/0.05\% Tween-20 (Bio-Rad, Munich, Germany) and subsequently 3 times in TBS for 5-10 min each. The secondary antibody, goat antirabbit horseradish peroxidase (stock solution $400 \mu \mathrm{g} / \mathrm{ml}$; DakoCytomation, Denmark), was incubated at a dilution of 1:1000 for 1 additional hour at room temperature followed by 5 washing steps as described above. Detection of bound antibodies was accomplished by membrane development using the ECL Plus Western Blotting Detection System (Amersham Biosciences, Cambridge, UK) for $5 \mathrm{~min}$, with subsequent development of the Hyperfilm ECL (Amersham). All expression data were confirmed in at least three independent experiments.

Preparation of nuclear extracts. According to previous applied protocols (19) with minor modifications, $5 \times 10^{7}$ cells $/ \mathrm{ml}$, were scratched from Petri dishes by the addition of $10 \mathrm{ml}$ phosphate-buffered saline (PBS). A cell line pellet was obtained by centrifugation (Beckman CS-6R) for 4 min at $800 \mathrm{rpm}$. After 2 washing steps with PBS, cells were re-suspended in $1 \mathrm{ml} \mathrm{PBS}$, transferred into a 1.5-ml tube and centrifuged at $4^{\circ} \mathrm{C}$ for $45 \mathrm{sec}$ at $14,000 \mathrm{rpm}$. The cell pellet was resuspended in $400 \mu \mathrm{l}$ ice cold buffer A [10 mM HEPES, pH 7.9, $10 \mathrm{mM} \mathrm{KCl}, 0.1 \mathrm{mM}$ EDTA, 0.1 mM EGTA, $1 \mathrm{mM}$ PMSF, $10 \mu \mathrm{l}$ complete protease inhibitor cocktail (Roche) and $1 \mathrm{mM}$ DTT] and incubated on ice for $15 \mathrm{~min}$. Cells were lysed by the addition of $25 \mu \mathrm{l}$ of $10 \% \mathrm{NP}-40$ and homogenized with 10 strokes in a dounce homogenizer at $4^{\circ} \mathrm{C}$ followed by centrifugation for $1 \mathrm{~min}$ at $14,000 \mathrm{rpm}$ for nuclei sedimentation. Supernatants were carefully removed and regarded as cytoplasmic fractions. Nuclear proteins were extracted by the addition of $50 \mu \mathrm{l}$ of buffer $\mathrm{C}$ [20 mM HEPES, pH 7.9, 0.4 M $\mathrm{NaCl}, 1 \mathrm{mM}$ EDTA, $1 \mathrm{mM}$ EGTA, $1 \mathrm{mM}$ PMSF, $0.1 \mu \mathrm{l}$ protease inhibitor cocktail (Roche)] and extensive shaking of the tubes for $20 \mathrm{~min}$ at $4^{\circ} \mathrm{C}$ in a tube shaker followed by centrifugation at $14,000 \mathrm{rpm}$ and $4^{\circ} \mathrm{C}$ for $5 \mathrm{~min}$. The supernatant was removed and stored in aliquots at $-80^{\circ} \mathrm{C}$. All steps were performed on ice.

Isolation of total RNA from tumor cell lines. Total RNA was isolated from cultured tumor cells as reported previously, including the digestion of contaminating DNA with the provided DNase $(20,21)$.

Analysis of mRNA expression levels in human GBM cell lines by semi-quantitative RT-PCR. To compare the expression of the individual genes examined, reverse transcriptionpolymerase chain reaction (RT-PCR) was performed using primers designed according to published information on Egr-1, $\beta$-actin and HIF-1 $\alpha$ mRNA sequences in GenBank (accession 

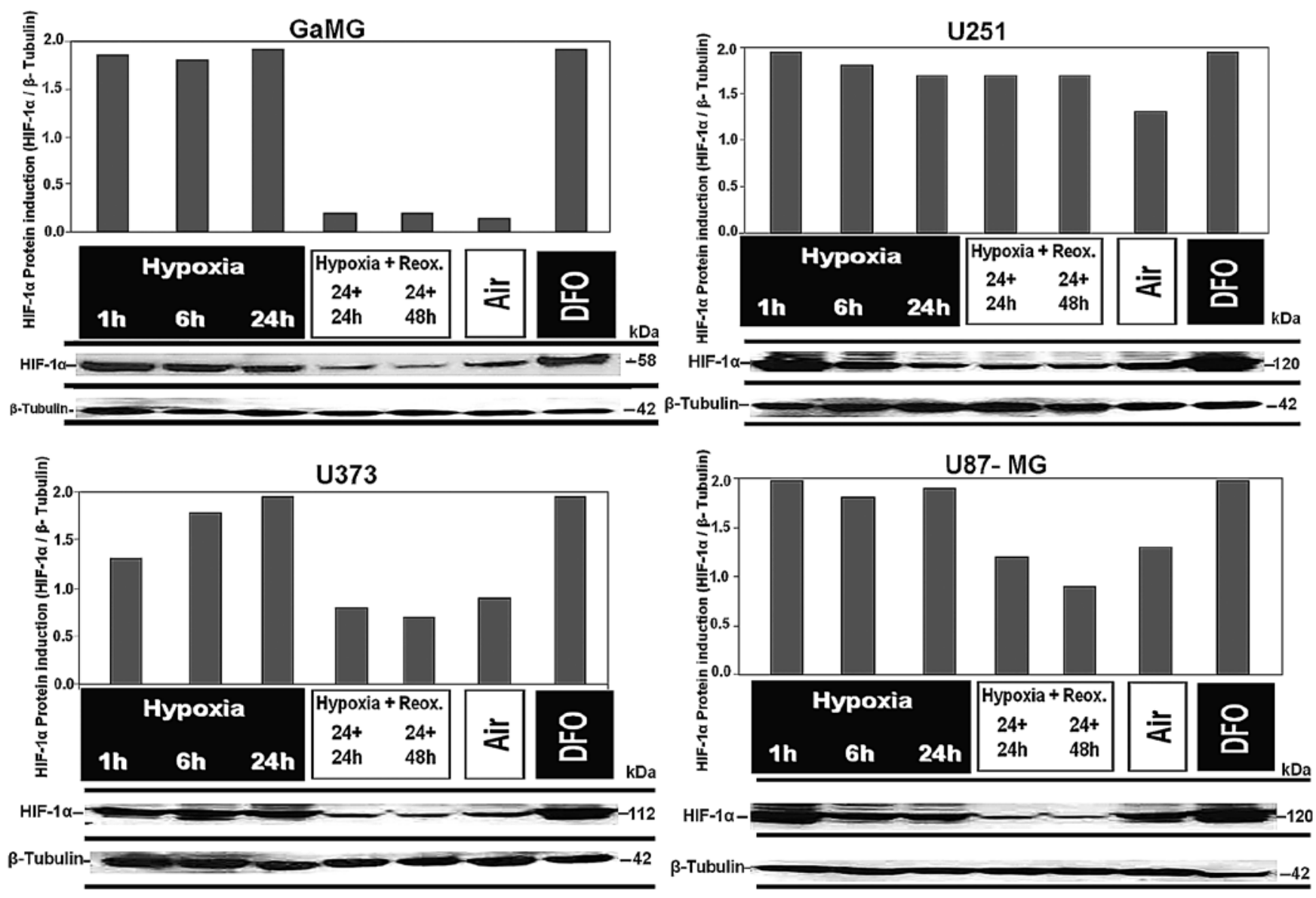

Figure 3. HIF-1 $\alpha$ protein expression under hypoxic conditions in glioblastoma in vitro. Western blot analysis showing regulation of hypoxia-inducible factor$1 \alpha$ (HIF-1 $\alpha$ ) expression at the protein level in vitro in human glioblastoma cell lines exposed to hypoxic conditions $\left(0.1 \% \mathrm{O}_{2}\right)$ for 1,6 or $24 \mathrm{~h}$. Nuclear protein extracts from cells subjected to $24 \mathrm{~h}$ under normoxia or to treatment with desferroxamine (DFO, $100 \mu \mathrm{M}$ ) served as the negative and positive control, respectively. $\beta$-tubulin served as the loading control. HIF- $1 \alpha$ protein expression level was shown as bar graphs after densitometric evaluation and normalization to the corresponding $\beta$-tubulin expression. HIF-1 $\alpha$ was strongly expressed after $1 \mathrm{~h}$ at $0.1 \% \mathrm{O}_{2}$, and remained increased for up to $24 \mathrm{~h}$ under hypoxia. A representative experiment of three is shown.

nos. NM_001964.2, NM_001101 and NM_001530.2, respectively). An aliquot of 1-5 $\mu \mathrm{g}$ of total mRNA from human glioblastoma cell lines was transcribed at $42^{\circ} \mathrm{C}$ for $1 \mathrm{~h}$ in a $20-\mu 1$ reaction mixture using $200 \mathrm{U}$ RevertAid $^{\mathrm{TM}} \mathrm{M}-\mathrm{MuLV}$ Reverse Transcriptase (RT), oligo(dT)18 primer and $40 \mathrm{U}$ Ribonuclease inhibitor (all from Fermentas, Ontario, Canada).

For PCR, primers were designed in flanking exons with Primer3 software (available online at http://frodo.wi.mit.edu/ cgi-bin/primer3/primer3_www.cgi). To produce a 348-bp amplification product of Egr-1, the forward primer (F1) was 5'-AGCTGGAGGAGATGATGCTG-3' (nucleotides 370-390 and the reverse primer (R1) was 5'-TGCCAGCCCCAGCGT CAAAG-3' (nucleotides 698-718). To produce a 668-bp amplification product of $\beta$-actin, the forward primer (F1) was 5'-CGTGCGTGACATTAAGGAGA'-3 (nucleotides 697-716) and the reverse primer (R1) was 5'-CACCTTCACCGTTCC AGTTT'-3 (nucleotides 1345-1364) and to produce a 233-bp amplification product of $\mathrm{HIF}-1 \alpha$, the forward primer $(\mathrm{F} 1)$ was 5'-TTACAGCAGCCAGACGATCA-3' (nucleotides 2516-2535) and the reverse primer (R1) was 5'-CCCTGC AGTAGGTTTCTGCT-3' (nucleotides 2729-2748). PCR was performed with 25-32 cycles with increments of 5 cycles using PCR systems and reagents acquired from Promega ${ }^{\mathrm{TM}}$ (Promega
$\mathrm{GmbH}$, Mannheim, Germany) and applied according to the manufacturer's instructions. The PCR products were separated on $2 \%$ agarose gels (Sigma-Aldrich, Steinheim, Germany) and visualized by ethidium bromide staining $(0.07 \mu \mathrm{g} / \mathrm{ml}$ ethidium bromide; Bio-Rad).

Densitometric evaluation. Signals detected and visualized by Western blotting and RT-PCRs were analysed with 1D Kodak Image Analysis Software. Signal strength was measured in Kodak light units and divided by the corresponding signals of the loading control $\beta$-tubulin and $\beta$-actin for Western blotting and $\beta$-actin for RT-PCR, as previously described (22-25).

\section{Results}

Comparative Egr-1 mRNA expression in human glioblastoma cells in vitro. To investigate the effect of controlled hypoxic conditions on Egr-1 mRNA expression, we performed in vitro cell culture assays under an oxygen concentration of $0.1 \% \mathrm{O}_{2}$ with and without reoxygenation. No regulatory effect of these different oxygenation conditions on Egr-1 expression was detectable by semi-quantitative RT-PCR in the human glioblastoma cell lines U87-MG, U251, U373 and GaMG (Fig. 1). 

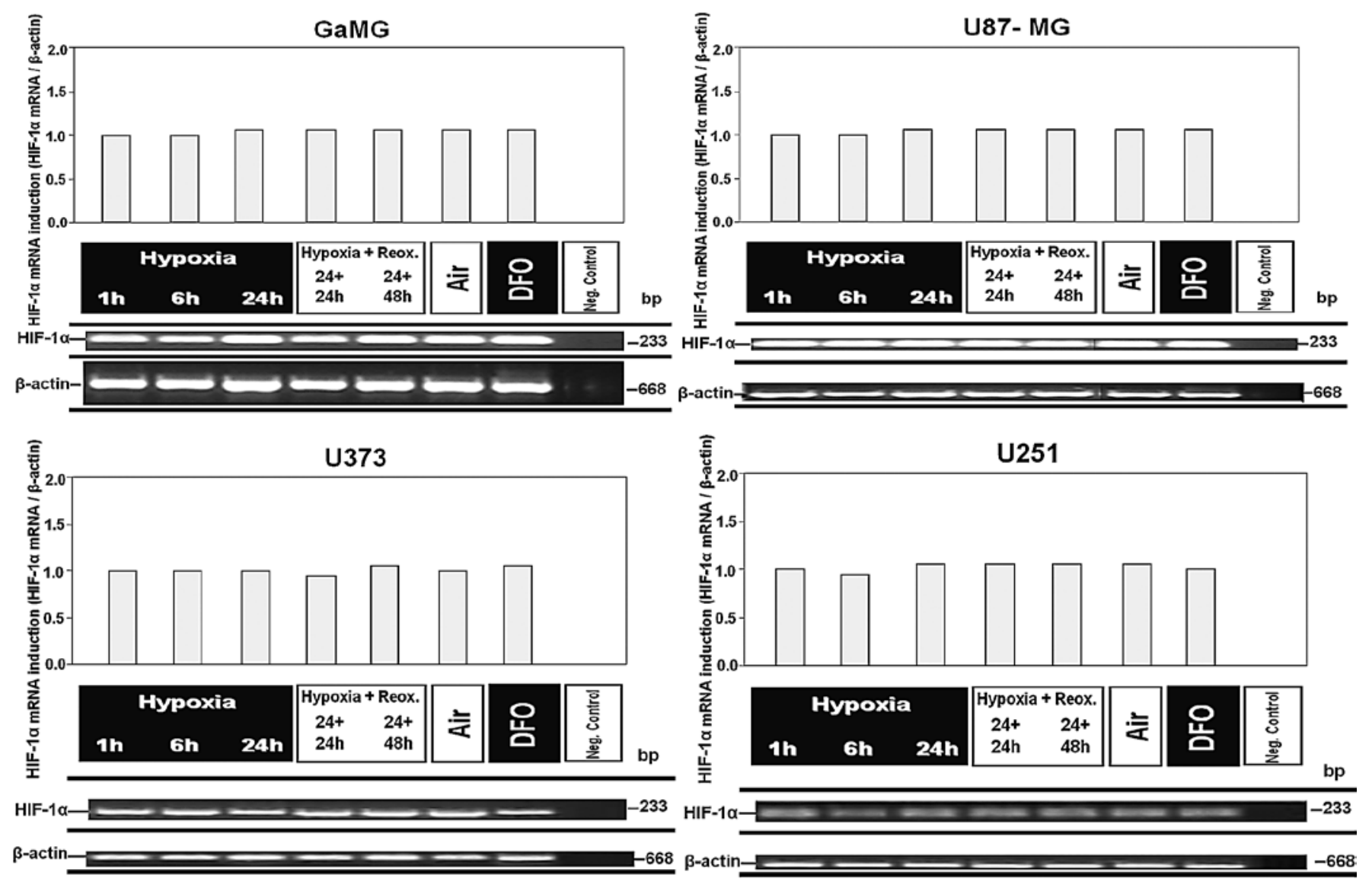

Figure 4. HIF-1 $\alpha$ mRNA expression under hypoxic conditions in glioblastoma in vitro. HIF-1 $\alpha$ mRNA expression in human U87-MG, U373, U251 and GaMG glioblastoma cell lines after the in vitro application of different hypoxic conditions. RT-PCR did not reveal any regulatory events under different oxygenation, hypoxia and reoxygenation conditions. Bar graphs show band intensities after densitometric evaluation and normalization to $\beta$-actin expression. A representative experiment of three is shown.

Densitometric evaluation confirmed these results. Together, these data suggest that the established formation of hypoxic regions within glioblastoma tumor tissue is not accompanied by an upregulation of Egr-1 mRNA.

Egr-1 protein expression in human glioblastoma cells in vitro. The glioblastoma cell lines GaMG, U373, U87-MG and U251 were cultured under hypoxic conditions as described above. These cells did not show any regulation of Egr-1 protein expression (Fig. 2) under the examined conditions. Egr-1 protein expression was not modified in response to different oxygenation, hypoxia or reoxygenation conditions in vitro in the tested glioblastoma cell lines. Densitometric evaluation of Western blotting confirmed these results.

$H I F-1 \alpha$ protein expression in response to in vitro hypoxia. HIF-1 $\alpha$ nuclear protein clearly responded with upregulation under hypoxic conditions and downregulation under reoxygenation or normoxic conditions in the U373, U251 and GaMG cells (Fig. 3). HIF-1 $\alpha$ was strongly expressed after $1 \mathrm{~h}$ at $0.1 \% \mathrm{O}_{2}$, remained increased after $24 \mathrm{~h}$ of hypoxia, and showed stable reduced expression upon reoxygenation for up to $48 \mathrm{~h}$ (Fig. 3). These results confirm the oxygen-dependent regulation of HIF-1 $\alpha$ at the protein level in the experimental models of the present study, and reaffirm that the experimental settings for the expression analysis of Egr-1 were suitable for the evaluation of regulatory events under hypoxic conditions.

HIF-1 a mRNA expression in response to in vitro hypoxia. Semi-quantitative RT-PCR of the glioblastoma cell lines GaMG, U373, U87-MG and U251 cultured under hypoxic conditions as described above revealed that HIF-1 $\alpha$ was evenly expressed in vitro in GaMG, U373, U87-MG and U251 glioblastoma cells. HIF-1 $\alpha$ mRNA expression was not influenced by hypoxic conditions, nor was the upregulation of HIF-1 $\alpha$ mRNA in glioblastoma cell lines detectable (Fig. 4).

\section{Discussion}

It has been postulated that the expression of several genes, such as PAI or CEBP- $1 \alpha$, is upregulated under hypoxia in tumor cells by the regulative activity of the transcription factor early growth response factor 1 (Egr-1) (26). The different origins of these tumor cells may be among the key factors that play a role during this process. The results of previous studies suggest that the transcription factor Egr-1 may be regulated by hypoxia, and that it represents the main transcription factor responsible for the hypoxia-induced regulation of the N-Myc downregulated gene 1 (NDRG1) in human 
tumor cells $(2,3)$. Other studies have identified hypoxiainduced genes that are not dependent on hypoxia-inducible factor- $1 \alpha(\mathrm{HIF}-1 \alpha)$. A large-scale microarray analysis that compared HIF-1 $\alpha$ and hypoxia-induced genes revealed that HIF-1 $\alpha$ was involved in the regulation of approximately half of the hypoxia-induced genes (27).

It has been suggested that HIF-1 $\alpha$ plays a key role in hypoxic response, in particular during tumorigenesis $(28,29)$. Our previous results indicate that exposure of the four glioma cell lines U373, U251, U87-M and GaMG to hypoxic aeration conditions results in the overexpression of NDRG1 (15-17, 30,31). Comparable hypoxia-mediated Egr-1 induction and activation were observed in cultured hepatoma-derived cells deficient in HIF-1 $\beta$ and in wild-type hepatoma cells, indicating that the HIF-1 and Egr-1 pathways are initiated independently in response to oxygen deprivation (31).

In the four glioblastoma cell lines examined, HIF-1 $\alpha$ was not regulated at the mRNA level, but was upregulated at the protein level under hypoxic conditions, However, neither Egr-1 mRNA nor Egr-1 protein showed any regulative pattern under identical aeration conditions. Therefore, HIF-1 $\alpha$ still represents a promising target for novel therapeutic strategies in cancer research. The discovery of new factors involved in its regulation is of great interest in the field. Based on the results which we present here for the first time, we can hypothesize that Egr-1 does not regulate NDRG1 transcription under hypoxic conditions, at least not in glioblastoma. This is in concordance with the findings of other studies. Moreover, the findings suggest that HIF- $1 \alpha$ plays an active role in the regulation of NDRG1 (15-17,30).

Our results suggest that Egr-1 activated by hypoxia may play an active role in the positive regulation of the activity of NDRG1 in various tumors, but not in human glioblastoma. However, based on the data presented here and on the results of prior studies, the main regulative function of Egr-1 may be carried out by the functional activities of HIF-1 $\alpha$. The discovery of novel actors involved in the regulation of Egr-1 is of great interest. We propose that the activation of Egr-1 in response to hypoxia induces a different facet of the adaptive response compared to HIF-1, despite the results observed in tumor cells of other origin. Further examination of Egr-1 expression in vivo should lead to an extensive understanding of the functional mechanisms involved in hypoxia-induced gene regulation in human brain cancer.

In conclusion, it is likely that the Egr-1 protein is an important nuclear intermediate in the signal transduction process under hypoxia, and one of the crucial targets in human carcinogenesis in different tissues, especially those of the brain. One proposed reason could be the complex regulatory mechanism of the Egr-1 gene, which most likely involves more than one signalling pathway for the hypoxia-induced regulation of Egr-1.

\section{Acknowledgements}

The authors thank Astrid Katzer and Stefanie Gerngras for their technical assistance during the stages of this analysis. This work was supported, in part, by a grant from the Deutsche Forschungsgemeinschaft (VO 871/2-3) to D.V. and by IZKF Würzburg (B25) to C.H. and G.H.V. Additionally, the authors would like to acknowledge the efforts and contributions made by research groups in tumor hypoxia, hypoxia signalling and regulation.

\section{References}

1. Akutagawa O, Nishi H, Kyo S, Terauchi F, Yamazawa K, Higuma C, Inoue $\mathrm{M}$ and Isaka K: Early growth response-1 mediates downregulation of telomerase in cervical cancer. Cancer Sci 99: 1401-1406, 2008.

2. Zhang P, Tchou-Wong KM and Costa M: Egr-1 mediates hypoxia-inducible transcription of the NDRG1 gene through an overlapping Egr-1/Sp1 binding site in the promoter. Cancer Res 67: 9125-9133, 2007.

3. Ellen T, Ke Q, Zhang P and Costa M: NDRG1, a growth and cancer related gene: regulation of gene expression and function in normal and disease states. Carcinogenesis 29: 2-8, 2008.

4. Wang GL, Jiang BH, Rue EA and Semenza GL: Hypoxiainducible factor 1 is a basic-helix-loop-helix-PAS heterodimer regulated by cellular $\mathrm{O}_{2}$ tension. Proc Natl Acad Sci USA 92: 5510-5514, 1995.

5. Iwai K, Yamanaka K, Kamura T, et al: Identification of the von Hippel-Lindau tumor-suppressor protein as part of an active E3 ubiquitin ligase complex. Proc Natl Acad Sci USA 96: 12436-12441, 1999.

6. Lisztwan J, Imbert G, Wirbelauer C, Gstaiger M and Krek W: The von Hippel-Lindau tumor suppressor protein is a component of an E3 ubiquitin-protein ligase activity. Genes Dev 13: 18221833, 1999.

7. Cockman ME, Masson N, Mole DR, Jaakkola P, Chang GW, Clifford SC, Maher ER, Pugh CW, Ratcliffe PJ and Maxwell PH: Hypoxia inducible factor-alpha binding and ubiquitylation by the von Hippel-Lindau tumor suppressor protein. J Biol Chem 275: 25733-25741, 2000.

8. Kamura T, Sato S, Iwai K, Czyzyk-Krzeska M, Conaway RC and Conaway JW: Activation of HIF1alpha ubiquitination by a reconstituted von Hippel-Lindau (VHL) tumor suppressor complex. Proc Natl Acad Sci USA 97: 10430-10435, 2000.

9. Ohh M, Park CW, Ivan M, Hoffman MA, Kim TY, Huang LE, Pavletich N, Chau V and Kaelin WG: Ubiquitination of hypoxiainducible factor requires direct binding to the beta-domain of the von Hippel-Lindau protein. Nat Cell Biol 2: 423-427, 2000.

10. Tanimoto K, Makino Y, Pereira T and Poellinger L: Mechanism of regulation of the hypoxia-inducible factor- 1 alpha by the von Hippel-Lindau tumor suppressor protein. EMBO J 19: 4298-4309, 2000.

11. Melillo G, Musso T, Sica A, Taylor LS, Cox GW and Varesio L: A hypoxia-responsive element mediates a novel pathway of activation of the inducible nitric oxide synthase promoter. J Exp Med 182: 1683-1693, 1995.

12. Dachs GU, Patterson AV, Firth JD, Ratcliffe PJ, Townsend KM, Stratford IJ and Harris AL: Targeting gene expression to hypoxic tumor cells. Nat Med 3: 515-520, 1997.

13. Gu YZ, Hogenesch JB and Bradfield CA: The PAS superfamily: sensors of environmental and developmental signals. Ann Rev Pharmacol Toxicol 40: 519-561, 2000.

14. Said HM, Polat B, Hagemann C, et al: Rapid detection of the hypoxia-regulated CA-IX and NDRG1 gene expression in different glioblastoma cells in vitro. Oncol Rep 20: 413-419, 2008.

15. Said HM, Stein S, Hagemann C, et al: Oxygen-dependent regulation of NDRG1 in human glioblastoma cells in vitro and in vivo. Oncol Rep 21: 237-246, 2009.

16. Said H, Stein S, Staab A, Katzer A, Flentje M and Vordermark D: NDRG1 is regulated in human glioblastoma in vitro as a consequence to the changing concentrations of the oxygen microenviroment. FEBS J 273 (s1): 345, 2006.

17. Said HM, Stein S, Hagemann C, Polat B, Schömig B, Staab A, Theobald M, Flentje M and Vordermark D: NDRG1 regulation as a response to an alternating hypoxic microenviroment in vivo and in vitro in human brain tumors. FEBS J 274 (S1): 281, 2007.

18. Akslen LA, Andersen KJ and Bjerkvig R: Characteristics of human and rat glioma cells grown in a defined medium. Anticancer Res 8: 797-803, 1988.

19. Vordermark D, Katzer A, Baier K, Kraft P and Flentje M: Cell type-specific association of hypoxia-inducible factor-1 $\alpha$ (HIF-1 $\alpha)$ protein accumulation and radiobiologic tumor hypoxia. Int $\mathbf{J}$ Radiat Oncol Biol Phys 58: 1242-1250, 2004. 
20. Said HM, Hagemann C, Staab A, Stojic J, Kühnel S, Vince GH, Flentje M, Roosen K and Vordermark D: Expression patterns of the hypoxia-related genes osteopontin, CA9, erythropoietin, VEGF and HIF-1alpha in human glioma in vitro and in vivo. Radiother Oncol 83: 398-405, 2007.

21. Hagemann C, Anacker J, Gerngras S, Kühnel S, Said HM, Patel R, Kämmerer U, Vordermark D, Roosen K and Vince GH: Expression analysis of the autosomal recessive primary microcephaly genes MCPH1 (microcephalin) and MCPH5 (ASPM, abnormal spindle-like, microcephaly associated) in human malignant gliomas. Oncol Rep 20: 301-308, 2008

22. Said HM, Katzer A, Flentje M, et al: Response of the plasma hypoxia marker osteopontin to in vitro hypoxia in human tumor cells. Radiother Oncol 76: 200-205, 2005.

23. Dooley S, Said HM, Gressner AM, et al: Y-box protein-1 is the crucial mediator of antifibrotic interferon-gamma effects. J Biol Chem 281: 1784-1795, 2006.

24. Said HM, Hagemann C, Stojic J, et al: GAPDH is not regulated in human glioblastoma under hypoxic conditions. BMC Mol Biol 8: 55, 2007.

25. Said HM, Staab A, Hagemann C, et al: Distinct patterns of hypoxic expression of carbonic anhydrase IX (CA IX) in human malignant glioma cell lines. J Neurooncol 81: 27-38, 2007.
26. Liao H, Hyman MC, Lawrence DA and Pinsky DJ: Molecular regulation of the PAI-1 gene by hypoxia: contributions of Egr-1, HIF-1alpha, and C/EBPalpha. FASEB J 21: 935-949, 2007.

27. Manalo DJ, Rowan A, Lavoie T, et al: Transcriptional regulation of vascular endothelial cell responses to hypoxia by HIF-1. Blood 105: 659-669. 2005

28. Ravi R, Mookerjee B, Bhujwalla ZM, et al: Regulation of tumor angiogenesis by $\mathrm{p} 53$-induced degradation of hypoxia-inducible factor $1 \alpha$. Genes Dev 14: 34-44, 2000.

29. Greijer AE, van der Groep P, Kemming D, et al: Up-regulation of gene expression by hypoxia is mediated predominantly by hypoxia-inducible factor 1 (HIF-1). J Pathol 206: 291-304, 2005.

30. Said HM, Hagemann C, Anacker J, Stein S, Polat B, Staab A, Flentje M, Theobald M, Roosen K and Vordermark D: Analysis of HIF-1alpha regulated gene expression in human brain tumors. FEBS J 275 (Suppl 1): 344, 2008

31. Yan SF, Lu J, Zou YS, Soh-Won J, Cohen DM, Buttrick PM, Cooper DR, Steinberg SF, Mackman N, Pinsky DJ and Stern DM: Hypoxia-associated induction of early growth response-1 gene expression. J Biol Chem 274: 15030-15040, 1999. 